\title{
Investigating the use of high performance concrete in partially prestressed beams and optimization of partially prestressed ratio
}

\author{
Yousef Zandi $^{{ }^{*}}$, Yasemin Akgün ${ }^{2}$ and Ahmet Durmuş ${ }^{3}$ \\ ${ }^{1}$ Department of Civil Engineering, Tabriz Branch, Islamic Azad University, Tabriz, Iran. \\ ${ }^{2}$ Civil Engineering Department, Ordu University, Ordu, Turkey \\ ${ }^{3}$ Civil Engineering Department, Karadeniz Technical University University, Trabzon, Turkey \\ Zandi@iaut.ac.ir
}

\begin{abstract}
The main objective of this study is to investigate the behaviour of partially prestressed concrete (PPC) beams subjected to pure flexure. The test beams were produced using both high performance concrete (HPC) and traditional concrete (TC). Test beams were compared with each other for strength, strain and cracking cases. The comparison was done by theoretical and experimental methods. Test measurements included failure loads, deflections, strains in concrete and steels, failure moments and service moments, experimental safety coefficients, number of cracks, crack widths, curvatures. Thus, optimum partially prestress ratio was determined for HPC and TC. Advantages of using HPC in partially prestressed beams were brought out. According to the results of the study, optimum partially prestress ratio for PPC beams produced using traditional concrete is $\sim 60 \%$; while it is $\sim 70 \%$ when HPC is used. The test results are shown that the usage of HPC in PPC beams is more convenient than the TC under some boundaries and conditions.
\end{abstract}

Keywords: Beams, High performance concrete, Partially prestressed ratio.

Introduction

Chronologically, construction techniques were revealed as reinforced concrete, prestressed concrete and partially prestressed concrete. None of these techniques are substituted to each other. Each technique is used in its own conditions (Akgün, 2003). As known that, all structures must have stability, a sufficient strength, durability, ductility and stiffness but fully prestressed concrete construction technique is much lower ductility than reinforced concrete construction technique. So, it hasn't any adaptation property. According to this reason, partially prestressed concrete (PPC) construction technique that has adaptation property should be used especially at the active earthquake regions. Because, there are both active (prestressing steels) and passive (reinforcing steels) steels in sections of elements produced with PPC. PPC construction technique is obtained adaptation property by presence of passive reinforcement. Consequently, partially prestressed construction technique is more rational and economical than fully prestressed concrete construction technique under some boundaries and conditions (for buildings that are allowable for occurring crack or protected from bad weather conditions) (Durmuş, 1976, Durmuş et al., 1979;1982a).

From other aspect, in terms of strength and durability of concrete, it is clear that concrete components and steels used in structure elements produced by using partially and fully prestressed concrete construction technique have better performance than traditional construction techniques. To improve the performance of concrete, both compressive strength and workable of concrete should be increased. Concretes with high strength, workable and durable are named high performance concretes. Production of these concretes Research article (C)Indian Society for Education and Environment (iSee) requires decreasing water/cement ratio and using chemical and mineral additives to improve the strength and workability. If failure mechanisms of concrete are considered, the three parameters such as strength of aggregates, quality of cement and adherence of aggregate-cement paste are required to be high for improve strength of concrete (Durmuş \& Pul, 1993; Akgun et al., 2009).

\section{Research significance}

This investigation attracts attention to using of partially prestressed concrete construction technique (because of ductility property) instead of fully prestressed concrete construction technique at the active earthquake regions. Advantages of using high performance concrete in partially prestressed beams are exposed. This study determines optimum partially prestressed ratios for partially prestressed beams produced by using high performance concrete and traditional concrete.

\section{Test program}

\section{Properties of test beams}

Test beams were produced by using both high performance concrete and traditional concrete. Test beams are compared to each other. There are nine series in total. The sizes of test beams are $100 \times 200 \times 2100 \mathrm{~mm}$. Reinforcement numbers of the test beams are given in Table 1. Reinforcement schemes and active reinforcement eccentricities of the test beams are illustrated in Fig. 1. Passive reinforcements of partially and fully prestressed concrete test beams were put into cross-section with corrosion space. Active reinforcements were put into beams as to theoretical eccentricity $(e=h / 6)$ which provides the stresses occurred at top of fibre of beam to be equal to zero. All of the beams, spacing and diameter of stirrups were chosen equal as $\varnothing 8 / 10$. 
Fig. 1. Reinforcement schemes of test beams.

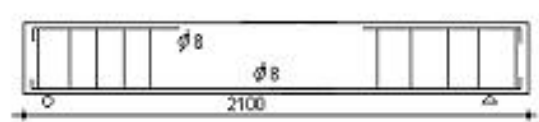

a) HP2 and T2 (A)

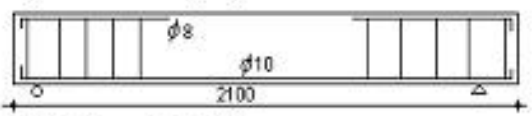

b) HP3 and T3 (A)

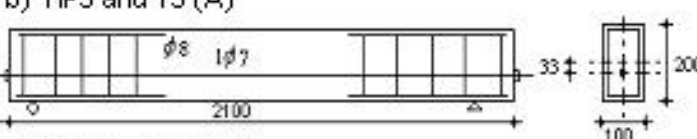

c) PHP1 and PT1 (F)

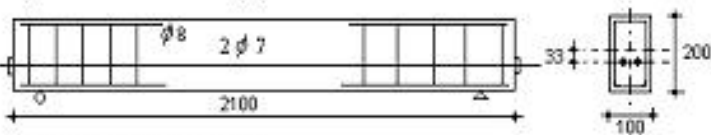

d) PHP2 and PT2 (F)
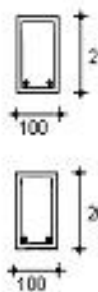

e) PPHP18 and PPT18 (C)

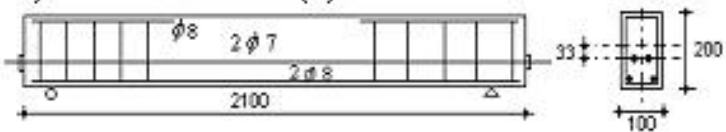

f) $\mathrm{PPHP} 28$ (E)

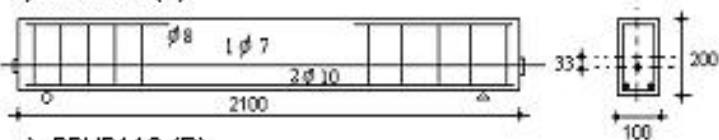

g) $\mathrm{PPHP} 110$ (日)

h) PPHP210 (D)

Fig. 2. Cross section of PPC beams, stresses, internal forces and moment arms.

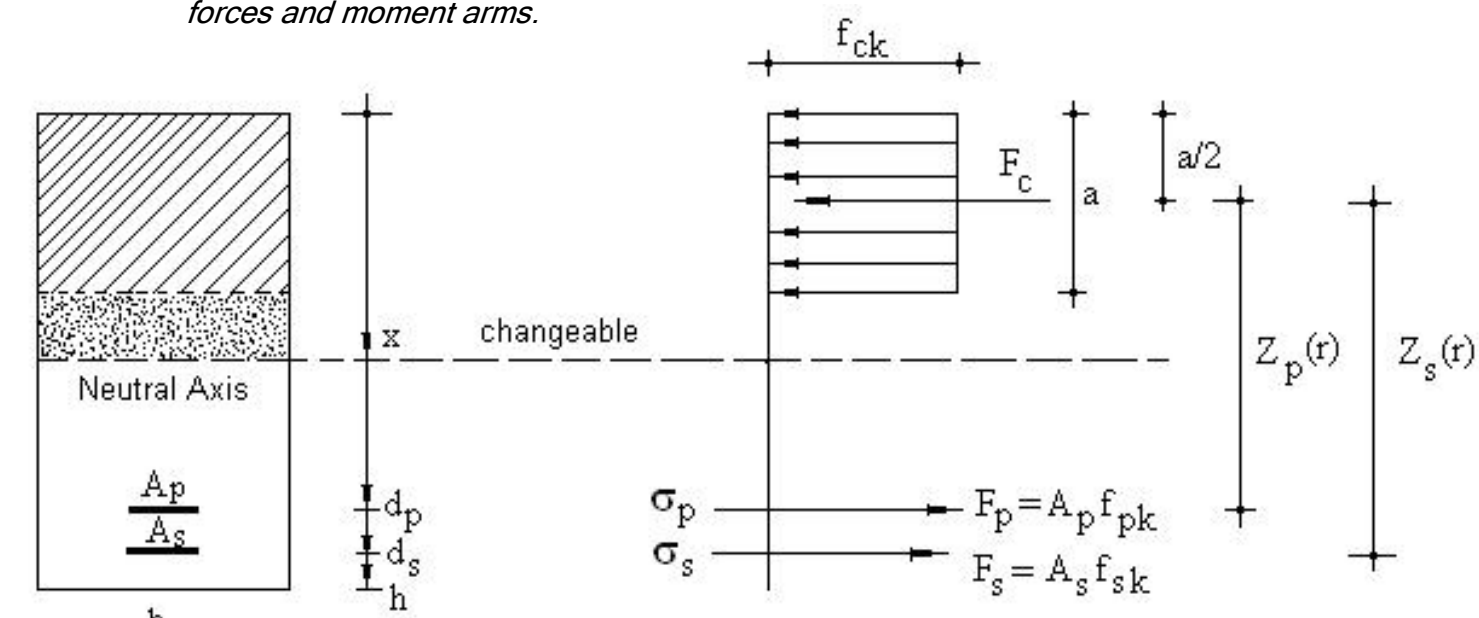

b) Stresses, internal forces and moment arms.

a) Cross section

Fig. 3. HP2-T2 Load-Strain.

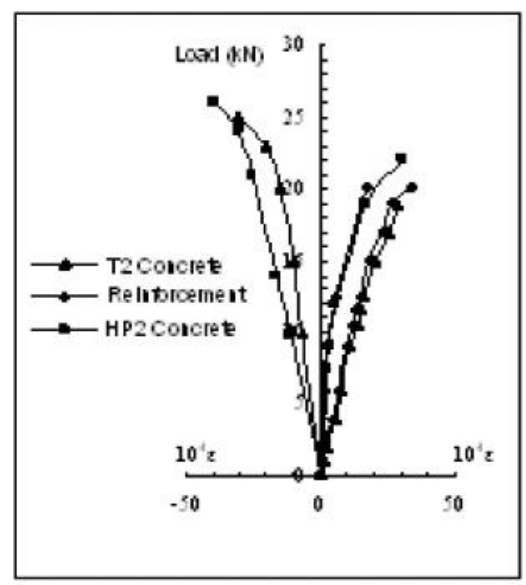

Research article

(C)Indian Society for Education and Environment (iSee)
Fig. 4. HP3-T3 Load-Strain.

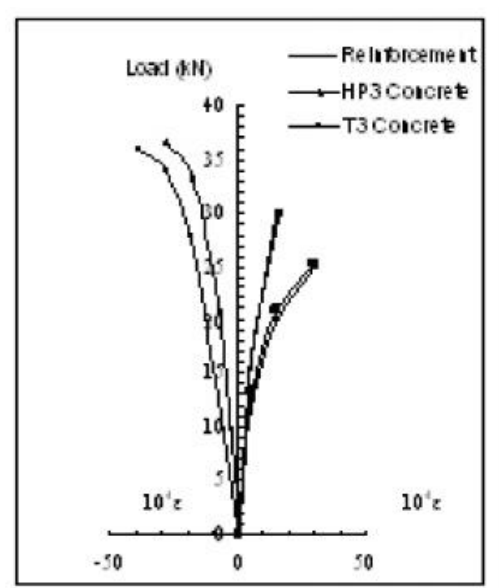

"High performance concrete" http://www.indjst.org
Fig. 5. PPHP110 Load-Strain.

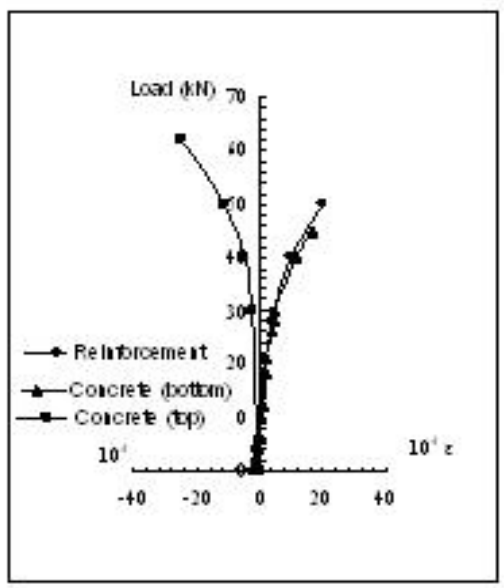

ISSN: 0974- 6846 
Table 1. Reinforcement numbers of the test beams

\begin{tabular}{|c|c|c|c|c|c|c|c|c|}
\hline \multirow[b]{2}{*}{$\begin{array}{l}\text { Beam } \\
\text { series }\end{array}$} & \multirow{2}{*}{$\begin{array}{l}\text { Codes of } \\
\text { Beams and } \\
\text { Types }\end{array}$} & \multicolumn{2}{|c|}{ Reinforcement } & \multirow[b]{2}{*}{ Stirrups } & \multirow[b]{2}{*}{ (\%PPR) } & \multicolumn{3}{|c|}{$\begin{array}{l}\text { Reinforcement } \\
\text { Ratio }\end{array}$} \\
\hline & & Active & Passive & & & $\begin{array}{l}\text { Totally } \\
\rho_{\text {top }}\end{array}$ & $\begin{array}{c}\text { Active } \\
\rho_{p}\end{array}$ & $\begin{array}{c}\text { Passiv } \\
\mathrm{e} \\
\rho_{\mathrm{s}}\end{array}$ \\
\hline 1 & HP1, T1 & - & - & - & - & - & - & - \\
\hline 2 & HP2,T2(A) & - & $2 \varnothing 8$ & $\varnothing 8 / 10$ & 0 & 0,0050 & - & 0,0050 \\
\hline 3 & HP3,T3(A) & - & $2 \varnothing 10$ & $\varnothing 8 / 10$ & 0 & 0,0079 & - & 0,0079 \\
\hline 4 & PPHP110(B) & $1 \varnothing 7$ & $2 \varnothing 10$ & $\varnothing 8 / 10$ & 40 & 0,0098 & 0,0019 & 0,0079 \\
\hline 5 & PPHP18(C) & 107 & $2 \varnothing 8$ & $\varnothing 8 / 10$ & 50 & 0,0069 & 0,0019 & 0,0050 \\
\hline 6 & PPT18 (C) & 107 & 208 & $\varnothing 8 / 10$ & 50 & 0,0069 & 0,0019 & 0,0050 \\
\hline 7 & PPHP210(D) & $2 \varnothing 7$ & $2 \varnothing 10$ & $\varnothing 8 / 10$ & 60 & 0,0117 & 0,0038 & 0,0079 \\
\hline 8 & PPHP28(E) & $2 \varnothing 7$ & $2 \varnothing 8$ & $\varnothing 8 / 10$ & 70 & 0,0088 & 0,0038 & 0,0050 \\
\hline 9 & PHP1,PT1(F) & $1 \varnothing 7$ & - & $\varnothing 8 / 10$ & 100 & 0,0019 & 0,0019 & - \\
\hline 9 & PHP2,PT2(F) & 207 & - & $\varnothing 8 / 10$ & 100 & 0,0038 & 0,0038 & - \\
\hline
\end{tabular}

Notes: 1) HPi; High Performance Reinforced Concrete Beam, 2) Ti; Traditional Reinforced

Concrete Beam, 3) PPHPab; Partially Prestressed Beam with High Performance

Concrete, 4) PPTab; Partially Prestressed Beam with Traditional Concrete a: Active

Reinforcemnet Number 107, 207 were coded as 1 and 2, b: Passive Reinforcement

Diameter Ø8, Ø10 were coded as 8 and 10,5) PHPa; Prestressed Beam with High

Performance Concrete, a: Active Reinforcement Number 1Ø7, 207 were coded as 1 and

2, 6) PTa; Prestressed Beam with Traditional Concrete, a: Active Reinforcement Number

1Ø7, 207 were coded as 1 and 2.

\section{Material properties}

The aggregate used in production of high performance concrete and traditional concrete was obtained from limestone rock that is provided from Trabzon, Meryemana region. The maximum aggregate size used is $16 \mathrm{~mm}$. To compare two different concretes, the granulometry of aggregates used in production of high performance concrete and traditional concrete are similar. This

Table 2. The granulometry of aggregates used in production of concretes

\begin{tabular}{|l|l|l|l|l|l|l|}
\hline $\begin{array}{l}\text { Granulometric } \\
\text { class }\end{array}$ & $\begin{array}{l}0-0,5 \\
(\mathrm{~mm})\end{array}$ & $\begin{array}{l}0,5-1,0 \\
(\mathrm{~mm})\end{array}$ & $\begin{array}{l}1,0-2,0 \\
(\mathrm{~mm})\end{array}$ & $\begin{array}{l}2,0-4,0 \\
(\mathrm{~mm})\end{array}$ & $\begin{array}{l}4,0-8,0 \\
(\mathrm{~mm})\end{array}$ & $\begin{array}{l}8,0-16,0 \\
(\mathrm{~mm})\end{array}$ \\
\hline $\begin{array}{l}\text { Total Weight } \\
(\%)\end{array}$ & 15 & 7 & 10 & 15 & 23 & 30 \\
\hline
\end{tabular}
calculated using Eq. (1) (Akgün, 2003; Durmuş \& Pul, 1993; Naaman, 1992). Partially prestressed ratios of test beams which is calculated using Eq. (1) are given in Table 5 .

$$
P P R=\frac{M_{p}}{M_{p}+M_{s}}=\frac{A_{p} \cdot f_{p k} \cdot Z_{p}(r)}{A_{p} \cdot f_{p k} \cdot Z_{p}(r)+A_{s} \cdot f_{s k} \cdot Z_{s}(r)}
$$

\section{Production of test beams and storing}

Test beams are produced using high performance concrete (HPC) and traditional concrete (TC). Beams which are reinforced concrete, partially prestressed concrete and fully prestressed concrete have partially prestressed ratios that are varied in the range of granulometry is given in Table 2 .

Cements used in production of concretes were derived from Unye Cement Factory. Cements used in production of high performance concrete and traditional concrete are respectively PÇ42.5 (PC: Portland cement) and KÇ52.5 (KÇ: Blended Cement). The number 32.5 and 52.5 denotes its characteristic compressive strenght in MPa. Drinking water is used in the mixing.

High performance concrete composition is different from traditional concrete composition. There are silica fume that is in the proportion by $10 \%$ of cement mass and superfludifier additive named Sikament FF that is in the proportion by $3 \%$ of cement mass + silica fume mass as different from traditional concrete composition in the high performance concrete composition. The mix design of concretes is made by Absolute Volumetric Method (TS802). The mix design results are given in Table 3. Physical and mechanical properties of concretes are given in Table 4 . In productions of test beams were used $\varnothing 8$ and $\varnothing 10$ diameter ribbed passive reinforcing steels and $\varnothing 7$ diameter with low relaxation active reinforcing steels. beams was applied by using pre- tension method. Prestressed force on active reinforcement $(P=55 \mathrm{kN})$ was transferred to beams 14 days later from concrete dump. Beams are held under wet sack during 21 days. In order to obtain better adhesion when are glued strain gauges to beams before testing, they were kept in a room with a temperature of $20^{\circ} \mathrm{C} \pm 5^{\circ} \mathrm{C}$ and humidity of $70 \% \pm 5 \%$. Flexure testing was performed at the end of 28 day period.

Failure analysis of beams

\begin{tabular}{|c|c|c|}
\hline Components & $\begin{array}{c}\text { High } \\
\text { Performance } \\
\text { Concrete }\end{array}$ & $\begin{array}{l}\text { Traditional } \\
\text { Concrete }\end{array}$ \\
\hline Total Aggregate $\left(\mathrm{kg} / \mathrm{m}^{3}\right)$ & 1794 & 1849 \\
\hline Absorbed Water $\left(\mathrm{kg} / \mathrm{m}^{3}\right)$ & 11.74 & 12.10 \\
\hline Water $\left(\mathrm{kg} / \mathrm{m}^{3}\right)$ & 150 & 175 \\
\hline Cement $\left(\mathrm{kg} / \mathrm{m}^{3}\right)$ & 500 & 350 \\
\hline Silica Fume $\left(\mathrm{kg} / \mathrm{m}^{3}\right)$ & 50 & - \\
\hline Fludifier $\left(\mathrm{kg} / \mathrm{m}^{3}\right)$ & 16.5 & - \\
\hline
\end{tabular}

Load-strain and load-deflection diagrams of test beams obtained from flexure test are illustrated from Fig. 3 to Fig. 12. According to the results of experimental 
Indian Journal of Science and Technology

Fig. 6. PPHP18 Load-Strain.

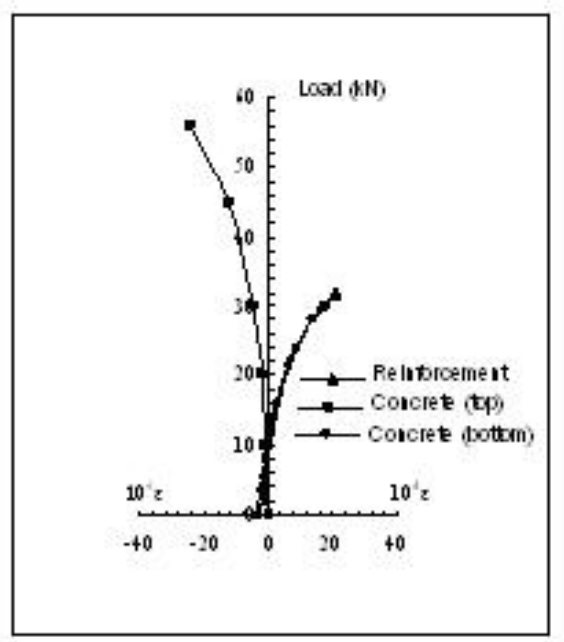

Fig. 9. PPHP28 Load-Strain.

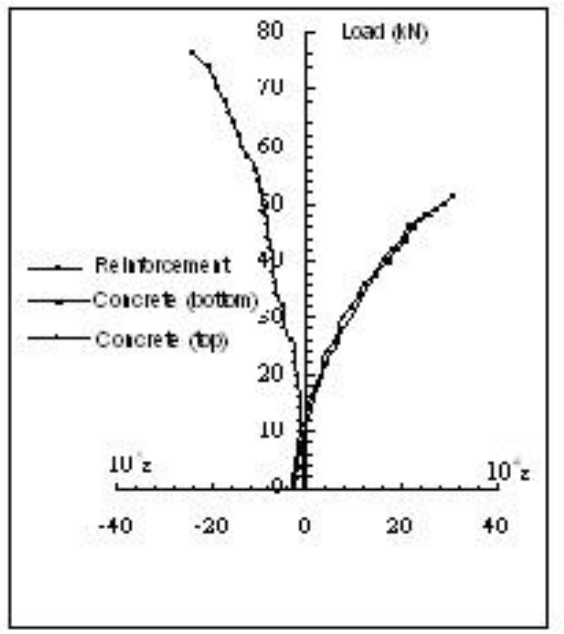

Fig. 12. Load-Deflection

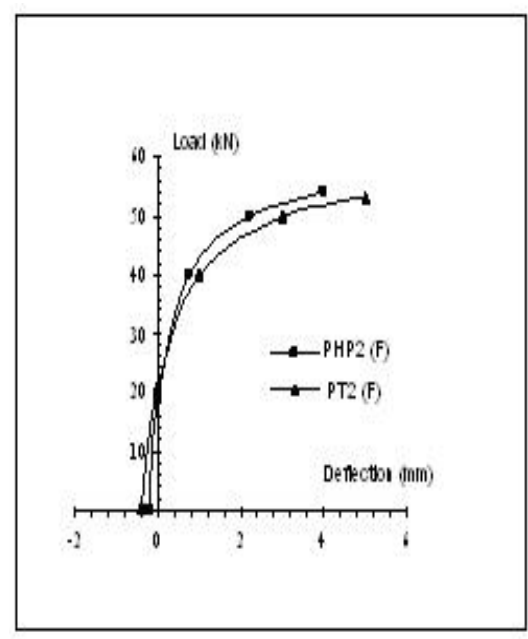

Research article

COIndian Society for Education and Environment (iSee)
Fig. 7. PPT18 Load-Strain

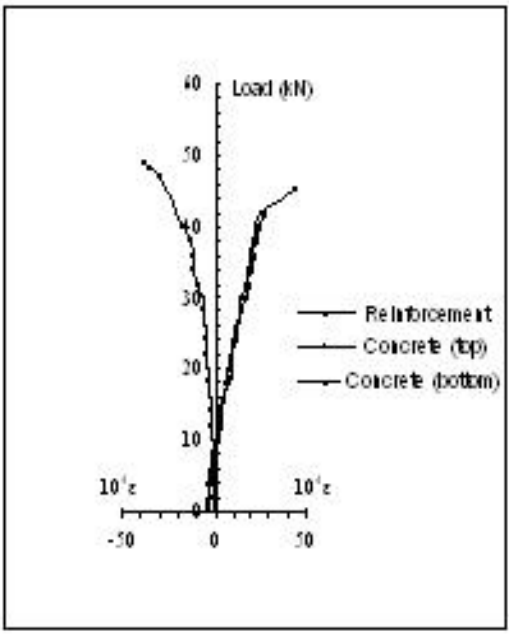

Fig. 10. HP2-HP3-T2-T3 LoadDeflection.

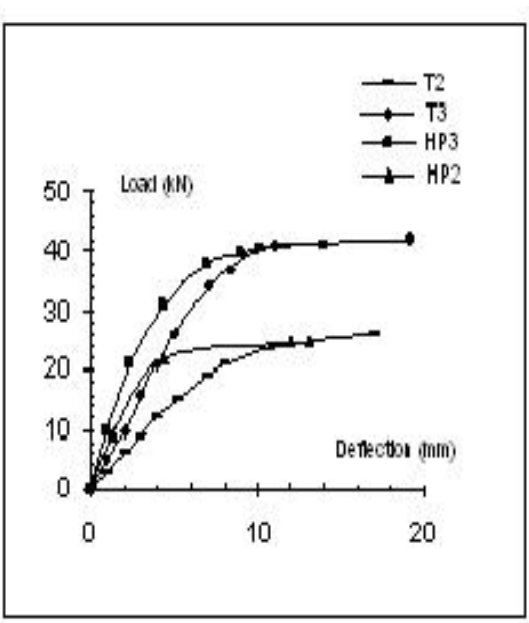

Fig. 8. PPHP210 Load-Strain

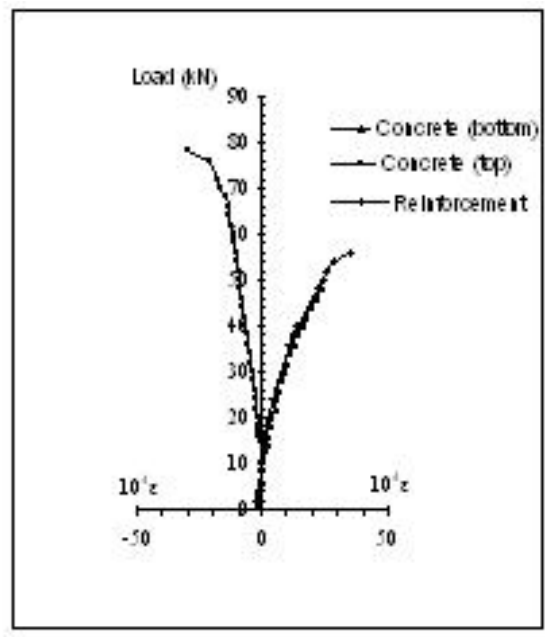

Fig. 11.Load-Deflection.

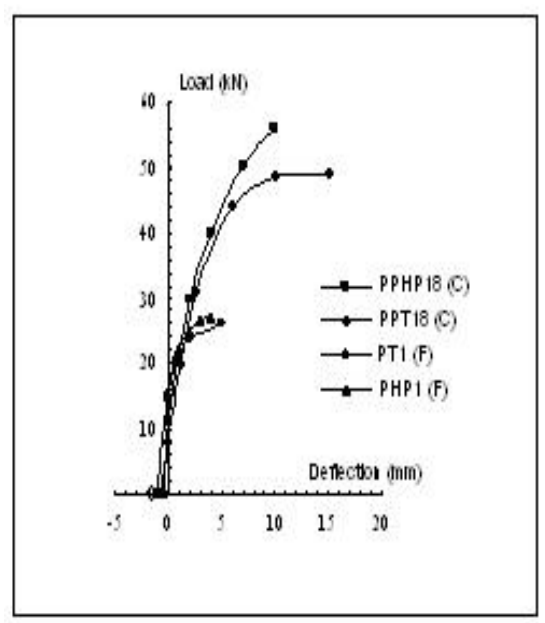

Fig. 13. Rigidity variations of test beams as to partially prestressed ratio.

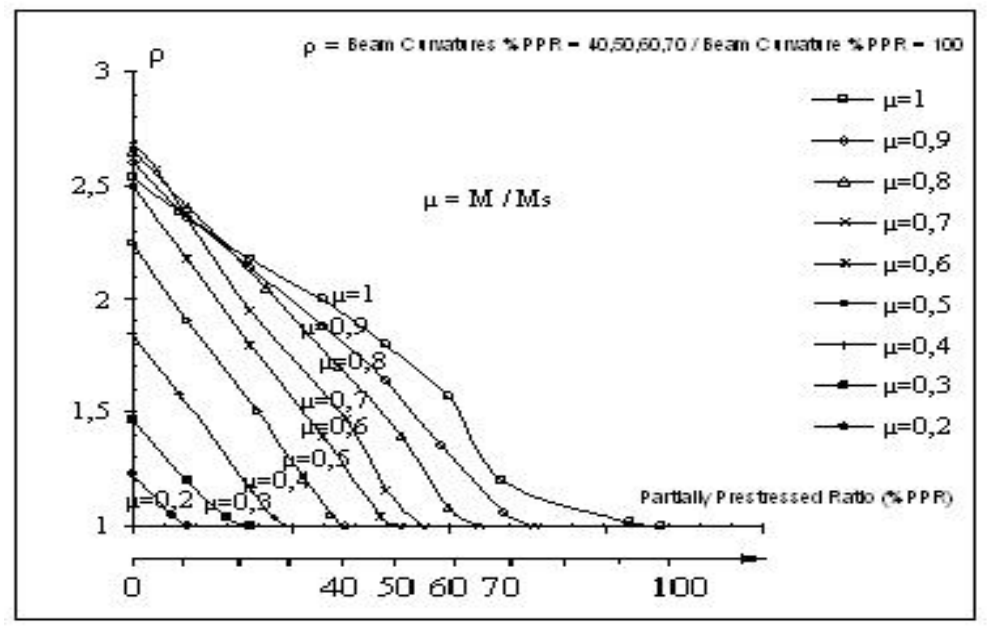

"High performance concrete" http://www.indjst.org

Y.Zandi et al. Indian J.Sci.Technol. 
Table 4. Physical and mechanical properties of concrete specimens

\begin{tabular}{|l|l|l|}
\hline Properties & $\begin{array}{l}\text { High } \\
\text { Performance } \\
\text { Concrete }\end{array}$ & $\begin{array}{l}\text { Traditional } \\
\text { Concrete }\end{array}$ \\
\hline Physical Properties & 2350 & 2300 \\
\hline Dry Unit Weight $\left(\mathrm{kg} / \mathrm{m}^{3}\right)$ & 2465 & 2415 \\
\hline Saturated Unit Weight $\left(\mathrm{kg} / \mathrm{m}^{3}\right)$ & \multicolumn{2}{|l|}{} \\
\hline Mechanical Properties & 66 & 35 \\
\hline $\begin{array}{l}\text { Average compressive } \\
\text { strength(MPa) }\end{array}$ & 61 & 33.60 \\
\hline $\begin{array}{l}\text { Characteristic compressive } \\
\text { strength (MPa) }\end{array}$ & 31000 & 27000 \\
\hline $\begin{array}{c}\text { Elasticity modules (MPa) } \\
\text { Poisson' s Ratio }\end{array}$ & 0.22 & 2.30 \\
\hline $10^{3} \varepsilon_{c o}$ & 2.42 & 0.20 \\
\hline
\end{tabular}

diagrams experimental failure load and deflections determined from experimental diagrams and theoretical moment $\left(\mathrm{M}_{\mathrm{rt}}\right)$, average moment $\left(\mathrm{M}_{\mathrm{rm}}\right)$, characteristic moment $\left(\mathrm{M}_{\mathrm{rk}}\right)$ and design moment $\left(\mathrm{M}_{\mathrm{rd}}\right)$ ultimate and ve service moments $\left(M_{s}\right)$, experimental ultimate moments $\left(M_{r e}\right)$ calculated from test results and the ratio of experimental ultimate moment to service moment is defined to be experimental safety coefficient $\gamma_{s}=M_{r e} / M_{s}, \quad \gamma_{r}=M_{r e} / M_{r t}, \quad \gamma_{r}^{*}=M_{r e} / M_{r m}$, $\gamma_{r}^{* *}=M_{r e} / M_{r k}$ and $\gamma_{r}^{* * *}=M_{r e} / M_{r d}$ are given in Table 6.

Table 5. Partially prestressed ratios (\%PPR)

\begin{tabular}{|l|c|c|c|c|c|c|}
\hline Type of beam & A & B & C & D & E & F \\
\hline $\begin{array}{l}\text { Partially Prestressed Ratio } \\
\text { (\%PPR) }\end{array}$ & 0 & 40 & 50 & 60 & 70 & 100 \\
\hline
\end{tabular}

A: Reinforced Concrete, B,C,D and E: Partially Prestressed Concrete, F: Fully Prestressed Concrete

\section{Analysis of cracking state of beams}

Crack number, average crack spacing, experimental, theoretical and characteristic crack width, experimental and theoretical first cracking moments, maximum unit elongations cause to first crack determined at instant failure and constant moment region of produced by using both high performance and traditional concrete reinforced, partially prestressed and fully prestressed concrete test beams are given Table 7 .

\section{Rigidity variations of beams}

In this study, rigidity variations of beams depending on partially prestressed ratio are investigated. The aim of this investigation is to determine the optimum partially prestressed ratio which does not completely lose conditions of adaptation properties of beams. Accordingly, ratio of partially prestressed produced by using high performance concrete beam curvature to fully prestressed produced by using high performance concrete beam curvature is defined as rigidity $(\rho)$. In determination of beam curvatures, the followings are used: applied moment to beam, elasticity module, inertia moment, and strain at the top and bottom fibres of beam, height of beam. PPR is defined as partially prestressed ratio. Applied moments ratio to beams is defined as ( $\mu$ $\left.=M / M_{s}\right)$. Variations of the three parameters are illustrated in Fig. 13. As seen from this figure, rigidities under service loads of beams increase rapidly until $70 \%$ values of partially prestressed ratio. Whereas, increasing the amount of rigidity is very slow for larger values of prestressed ratio. It is understood here that optimum partially prestressed ratio of partially prestressed concrete beams produced by using high performance concrete is approximately $70 \%$ in terms limitation of strain.

\section{Conclusion}

When investigation of cracking and failure state of unreinforced concrete beams (HP1, T1) and fully prestressed concrete beams is made (see Table 3 \& Table 4) although load carrying capacities of fully prestressed concrete beams increase, their cracking number doesn't change and a sudden and brittle failure occurs with a single crack as unreinforced concrete beams at under failure load and moment constant regions. It is understood that, there isn't adaptation property of fully prestressed concrete beams. But, behaviour of partially prestressed concrete beams with various partially prestressed ratios and sufficient passive reinforcement likes reinforced concrete beams. It is clear that, adaptation ability (ductility) is recovered in partially prestressed concrete beams because of passive reinforcement. In fact, this ability is expected from all structural elements and is especially very important at the active earthquake regions.

In this study, it was made comparisons on type of beams (C). According to this, experimental failure moments and safety coefficients of partially prestressed beams produced by using high performance concrete (PPHP) are higher than partially prestressed beams produced by using traditional concrete (PPT) but their average deflections are lower than PPT. Cracking numbers of PPHP are higher than PPT. Crack spacing and width of PPHP are lower than PPT. Experimental first cracking moments of PPHP are higher than PPT's. Unit elongations of PPHP are lower than PPT's. These indicators are shown that, bending behaviours of beams used high performance concrete improve from in many aspects. So, high performance concrete is preferred to traditional concrete in production of partially prestressed concrete beams.

In this study, comparisons were made on rigidities of partially and fully prestressed concrete beams. As results of these comparisons, optimum prestressed ratios are determined by improve the rigidity. These ratios for high performance concrete and traditional concrete are respectively $70 \%$ and $60 \%$.

Using high performance concrete in production of partially prestressed concrete structural elements 
Table 6. Analysis of failure of beams

\begin{tabular}{|c|c|c|c|c|c|c|c|c|}
\hline \multicolumn{9}{|c|}{ Experimental failure loads, deflections, failure and service moments } \\
\hline Type of beam & $\begin{array}{l}\text { Failure } \\
\text { Load } \\
(\mathrm{kN})\left(\mathrm{F}_{\mathrm{r}}\right)\end{array}$ & $\begin{array}{l}\text { Deflection } \\
(\mathrm{mm}) \\
\left(0,75 \mathrm{~F}_{\mathrm{r}}\right)\end{array}$ & $\begin{array}{l}\mathrm{M}_{\mathrm{re}} \\
(\mathrm{kNm})\end{array}$ & $\begin{array}{l}\mathrm{M}_{\mathrm{rt}} \\
(\mathrm{kNm})\end{array}$ & $\begin{array}{l}\mathrm{M}_{\mathrm{rm}} \\
(\mathrm{kNm})\end{array}$ & $\begin{array}{l}\begin{array}{l}M_{\mathrm{rk}} \\
(\mathrm{kNm})\end{array}\end{array}$ & $\begin{array}{l}\begin{array}{l}M_{\mathrm{rd}} \\
(\mathrm{kNm})\end{array}\end{array}$ & $\begin{array}{l}\mathrm{M}_{\mathrm{s}} \\
(\mathrm{kNm})\end{array}$ \\
\hline HP1 & 12,50 & - & 4,19 & - & - & - & - & - \\
\hline HP2 (A) & 25,00 & 4,82 & 8,38 & 7,90 & 6,57 & 6,33 & 5,48 & 3,65 \\
\hline HP3 (A) & 41,00 & 7,40 & 13,74 & 12,50 & 10,17 & 9,79 & 8,45 & 5,63 \\
\hline T1 & 7,00 & - & 2,35 & - & - & - & - & - \\
\hline $\mathrm{T} 2(\mathrm{~A})$ & 26,00 & 4,90 & 8,71 & 8,06 & 6,47 & 6,24 & 5,38 & 3,59 \\
\hline T3 (A) & 42,00 & 6,90 & 14,07 & 12,56 & 9,93 & 9,57 & 8,20 & 5,47 \\
\hline PPHP110(B) & 62,00 & 12,00 & 20,77 & 18,33 & 16,53 & 16,50 & 14,01 & 9,34 \\
\hline PPHP18 (C) & 56,00 & 10,00 & 18,76 & 16,14 & 13,24 & 13,19 & 11,24 & 7,49 \\
\hline PPT18 (C) & 49,00 & 15,00 & 16,42 & 13,89 & 12,47 & 12,43 & 10,38 & 6,92 \\
\hline PPHP210(D) & 80,00 & 8,00 & 27,47 & 24,20 & 22,39 & 22,18 & 18,50 & 12,33 \\
\hline PPHP28 (E) & 77,00 & 7,00 & 25,80 & 22,90 & 19,30 & 19,09 & 15,96 & 10,64 \\
\hline PHP2 (F) & 54,00 & 4,00 & 18,10 & 16,16 & 13,92 & 13,71 & 11,75 & 7,84 \\
\hline PT2 (F) & 53,00 & 5,00 & 17,80 & 15,90 & 14,02 & 13,91 & 11,63 & 7,74 \\
\hline \multicolumn{9}{|c|}{ Experimental safety coefficient. } \\
\hline Type of Beam & $\gamma_{s}$ & $\gamma_{r}$ & \multicolumn{2}{|l|}{$\gamma_{r}^{*}$} & \multicolumn{2}{|l|}{$\gamma_{r}^{* *}$} & \multicolumn{2}{|l|}{$\gamma_{r}^{* * * *}$} \\
\hline HP2 (A) & 2,30 & 1,06 & \multirow{2}{*}{\multicolumn{2}{|c|}{$\begin{array}{l}1,28 \\
1,35\end{array}$}} & \multicolumn{2}{|c|}{1,32} & \multicolumn{2}{|c|}{1,53} \\
\hline HP3 (A) & 2,44 & 1,10 & & & \multirow{2}{*}{\multicolumn{2}{|c|}{$\begin{array}{l}1,40 \\
1,40\end{array}$}} & \multirow{2}{*}{\multicolumn{2}{|c|}{$\begin{array}{l}1,63 \\
1,62\end{array}$}} \\
\hline T2 (A) & 2,43 & 1,08 & \multicolumn{2}{|c|}{1,35} & & & & \\
\hline T3 (A) & 2,57 & 1,12 & \multicolumn{2}{|c|}{1,42} & \multicolumn{2}{|c|}{1,47} & \multicolumn{2}{|c|}{1,72} \\
\hline PPHP110 (B) & 2,22 & 1,13 & \multicolumn{2}{|c|}{1,26} & \multicolumn{2}{|c|}{1,25} & \multicolumn{2}{|c|}{1,48} \\
\hline PPHP18 (C) & 2,50 & 1,16 & \multicolumn{2}{|c|}{1,42} & \multicolumn{2}{|c|}{1,48} & \multicolumn{2}{|c|}{1,67} \\
\hline PPT18 (C) & 2,37 & 1,18 & \multirow{2}{*}{\multicolumn{2}{|c|}{$\begin{array}{l}1,33 \\
1,23\end{array}$}} & \multirow{2}{*}{\multicolumn{2}{|c|}{$\begin{array}{l}1,32 \\
1,24\end{array}$}} & \multirow{2}{*}{\multicolumn{2}{|c|}{1,58}} \\
\hline PPHP210 (D) & 2,23 & 1,14 & & & & & & \\
\hline PPHP28 (E) & 2,42 & 1,13 & \multicolumn{2}{|c|}{1,34} & \multicolumn{2}{|c|}{1,35} & \multicolumn{2}{|c|}{1,62} \\
\hline PHP2 (F) & 2,31 & 1,12 & \multirow{2}{*}{\multicolumn{2}{|c|}{$\begin{array}{l}1,30 \\
1,27\end{array}$}} & \multicolumn{2}{|c|}{1,32} & \multicolumn{2}{|c|}{1,54} \\
\hline PT2 (F) & 2,30 & 1,12 & & & \multicolumn{2}{|c|}{1,28} & & \\
\hline
\end{tabular}

\section{References}

1. Akgün $Y$ (2003) Investigation of behavior of partially prestressed with high performance concrete beams, Ph.D. Thesis. Karadeniz Technical University, Trabzon, Turkey.

2. Durmuş A (1976) Contribution a letude des criteres de ruine d'élements de stuructures en bétonapplication aux piéces armées, thése de docteur ingenieur, Universite poul sabatier, insa no dordre 556, Toulouse, France.

3. Durmuş $A$, Arnaud $M$ and $M$ Lorrain (1979) Le Rôle des effects transversaux dans la fléxion des planchers nérvures en béton armé, consequénces sur la sécurité, annales de l' ITBTP, No: 376 Série EM/173, Paris. pp: $30-39$.

4. Durmuş A (1982) The effects on security of this system of mechanical behavior of fully prestressed and partially prestressed concrete beams which form an integral part of a floor together with the slabs, Phd thesis, Karadeniz Technical Univ., Trabzon, Turkey.

by compensation of constant load. In addition to Time dependent prestress losses which occur from shrinkage and creep will reduced by using high performance concrete.

At active earthquake regions, PPHP which has optimum partially prestressed ratio (PPR) is more convenient than fully prestressed concrete in monolithic and prefabric buildings.

Table 7. Analysis of cracking state of beams

5. Durmus A and Pul S (1993) The effect on mechanical properties of concrete of aggregate petrographic structure. Proc. Adv. Civil Eng., 1st Technical Congress, Gazi Mağusa-Cyprus. pp: 25-27, pp: 673684.

6. Akgun YA, Durmuş and Zandi Y (2009) Advantages of using high performance concrete in partially beams and optimization of partially pressurised ratio. Proc. $2^{\text {nd }}$ Int. Conf. Concrete Technol., Tabriz, Iran. pp: 6-7.

7. Naaman AE (1992) Unified design recommendations for reinforced, prestressed, and partially prestressed concrete bending and compression members. AC/ Structural J. 89, 200-210.

\begin{tabular}{|l|c|c|c|c|c|c|}
\hline $\begin{array}{l}\text { Type of } \\
\text { beam }\end{array}$ & $\begin{array}{l}\text { Crack } \\
\text { number }\end{array}$ & $\begin{array}{l}\text { Crack } \\
\text { spacing } \\
(\mathrm{mm})\end{array}$ & $\begin{array}{l}\text { Crack } \\
\text { Width } \\
(\mathrm{mm})\end{array}$ & $\begin{array}{l}\text { Experimental } \\
\text { moment } \\
(\mathrm{kNm})\end{array}$ & $\begin{array}{l}\text { Theoretical } \\
\text { moment } \\
(\mathrm{kNm})\end{array}$ & $\begin{array}{l}\text { Unit } \\
\text { elongation } \\
\left(10^{6} \varepsilon_{c t}\right)\end{array}$ \\
\hline HP1 & - & - & - & 2,68 & 2,37 & 100 \\
\hline HP2 (A) & 10 & 80 & 1,00 & 3,48 & 2,51 & 105 \\
\hline HP3 (A) & 13 & 76 & 0,90 & 4,22 & 2,62 & 105 \\
\hline T1 & - & - & - & 2,01 & 1,76 & 100 \\
\hline T2 (A) & 7 & 98 & 0,90 & 2,81 & 1,89 & 110 \\
\hline T3 (A) & 9 & 85 & 0,80 & 3,08 & 1,97 & 115 \\
\hline PPHP110(B) & 16 & 50 & 0,30 & 6,53 & 6,17 & 115 \\
\hline PPHP18(C) & 15 & 60 & 0,35 & 6,70 & 6,27 & 100 \\
\hline PPT18(C) & 5 & 90 & 0,80 & 5,51 & 5,03 & 110 \\
\hline PPHP210(D) & 13 & 68 & 0,40 & 6,80 & 6,28 & 115 \\
\hline PPHP28 (E) & 10 & 75 & 0,45 & 7,04 & 6,38 & 110 \\
\hline PHP2(F) & 1 & - & - & 6,32 & 5,98 & 100 \\
\hline PT2 (F) & 1 & - & - & 5,69 & 5,35 & 105 \\
\hline
\end{tabular}

